\title{
VIABILITY OF BAT SPERMATOZOA AFTER PROLONGED STORAGE IN THE EPIDIDYMIS
}

\author{
P. A. RACEY \\ Unit of Reproductive Biology, University of Liverpool, Life Sciences Building, \\ P.O. Box 147, Liverpool L69 $3 B X$
}

(Received 27th August 1971, accepted 30th September 1971)

The viability of spermatozoa after prolonged storage in the female reproductive tract has been established in several species of hibernating bats (Wimsatt, 1944; Hiraiwa \& Uchida, 1956; Racey \& Kleiman, 1970). Spermatozoa are, however, also stored in the cauda epididymidis of male bats during winter (Courrier, 1927). Although mating is initiated soon after the completion of spermatogenesis in late summer, its occurrence has frequently been reported during winter (Wimsatt, 1945) and spring (Moffat, 1922), and Strelkov (1962) showed that an increasing proportion of four vespertilionid species were inseminated as hibernation progressed.

Investigation of the viability of spermatozoa stored in the cauda epididymidis of hibernating bats has only recently become possible now that one species, the noctule (Nyctalus noctula), is maintained and bred in the laboratory (Racey, 1970). The annual reproductive cycle of captive noctules has been followed by observations of behaviour and external morphology, and details have been confirmed by histological examination. These studies have shown that spermatozoa are released from the testis during August and pass into the cauda epididymidis which becomes visibly distended. The seminiferous tubules shrink and spermatogenesis is not initiated again until the following spring. Copulation usually takes place in captive noctules in September and October (Kleiman \& Racey, 1969) and, as a result, the uterus becomes engorged with semen. The vagina is then occluded with connective tissue (Grosser, 1903). Ovulation takes place in spring and the young are born in midsummer (Wimsatt, 1969).

In the present series of experiments, twenty male noctules, caged individually, were not allowed to mate at the usual time and twenty-nine females were introduced to them at intervals during the winters of 1969-70 and 1970-71. Females were separated from males during April and inspected daily for evidence of conception. Young were born during June. Since the time of insemination was not known, the period between distension of the cauda epididymidis of males, and the time when females were introduced to them, was regarded as the minimum demonstrated duration of sperm storage in the epididymis (Table 1).

Fetuses and neonates were morphologically normal and the results show that noctule spermatozoa are viable after storage for at least 5 months in the cauda epididymidis. In other mammalian orders, the maximal period for which 
spermatozoa can be retained in the cauda epididymidis before fertility is impaired is 3 weeks (Tesh \& Glover, 1969). The low conception rate $(5 / 29=$ $17 \%$ ) in the present experiments must be interpreted with caution, as it may reflect the difficulties of breeding noctules in captivity. Alternatively, it may suggest that prolonged storage of epididymal spermatozoa plays a relatively unimportant part in the breeding cycle of this species, and that young are usually born as a result of autumn matings.

In three females which died during winter, connective tissue hyperplasia had rendered the cervix and upper vagina imperforate, and this may have prevented insemination, since the reproductive tracts were devoid of spermatozoa. It is possible, therefore, that the spermatozoa responsible for the conceptions listed in Table 1 were retained in the epididymis until vaginal changes at the time of ovulation facilitated successful insemination.

TABLE 1

RESULTS OF DELAYED MATING EXPERIMENTS

\begin{tabular}{|c|c|c|c|}
\hline Female & $\begin{array}{c}\text { Date of introduction } \\
\text { to male }\end{array}$ & $\begin{array}{l}\text { Result of } \\
\text { subsequent } \\
\text { conception }\end{array}$ & $\begin{array}{l}\text { Minimum duration } \\
\text { of sperm storage } \\
\text { by male (months) }\end{array}$ \\
\hline $\begin{array}{l}1 \\
2 \\
3\end{array}$ & $\begin{array}{l}\text { 30th Nov. '70 } \\
\text { 30th Nov. '70 } \\
\text { 3rd Dec. '70 }\end{array}$ & $\begin{array}{c}\text { Male born } \\
\text { Male twins born } \\
\text { 12-mm c to } r \text { male fetus }\end{array}$ & $\begin{array}{l}3 \\
3 \\
3\end{array}$ \\
\hline 4 & 2nd Feb. ${ }^{3} 70$ & $\begin{array}{c}\text { 9-mm c to } r \text { male fetus } \\
\text { (aborted) }\end{array}$ & 5 \\
\hline 5 & 27th Jan. '71 & Male born $\uparrow$ & 5 \\
\hline
\end{tabular}

c to $r=$ crown to rump.

* Uterine haemorrhage.

$\dagger$ Malpresentation, delivered by Caesarean section.

Captive noctules frequently arouse from hibernation and spend a considerable proportion of the winter in full metabolic activity. This causes depletion of their fat reserves to such an extent that it has been necessary to feed them twice a week during winter. It is unlikely, therefore, that the explanation of prolonged viability of epididymal spermatozoa lies solely in low body temperature and metabolic rate.

This work was initiated at the Wellcome Institute of Comparative Physiology, Zoological Society of London, and was supported by grants from the World Health Organization and the Ford Foundation. I am grateful to Mrs S. Tesh for examining the fetuses.

\section{REFERENCES}

Courrier, R. (1927) Etude sur le déterminisme des caractères sexuels secondaires chez quelques mammifères à l'activité testiculaire périodique. Archs Biol., Paris, 37, 173.

Grosser, O. (1903) Die physiologische bindegewebige Atresie des Genitalkanales von Vesperugo noctula nach erfolgter Kohabitation. Verh. anat. Ges., Jena, 17, 129.

Hirarwa, Y. K. \& Uchida, T. (1956) Fertilization in the bat Pipistrellus abramus abramus (Temminck). III. Fertilizing capacity of spermatozoa stored in the uterus after copulation in the fall. Sci. Bull. Fac. Agric. Kyushu Univ. 31, 565. 
KLeiman, D. G. \& RACEY, P. A. (1969) Observations on noctule bats (Nyctalus noctula) breeding in captivity. Lynx, 10, 65 .

Moffat, C. B. (1922) The habits of the long eared bat. Ir. Nat. 31, 105.

RACEY, P. A. (1970) The breeding, care and management of vespertilionid bats in the laboratory. Lab. Anim. 4, 171.

Racey, P. A. \& Kleiman, D. G. (1970) Maintenance and breeding in captivity of some vespertilionid bats, with special reference to the noctule $\mathcal{N} y c t a l u s$ noctula. Int. Zoo. $Y b .10,65$.

Strelxov, P. (1962) The peculiarities of reproduction in bats (Vespertilionidae) near the northern border of their distribution. Int. Symp. Meth. mammal. Invest. Brno 1960, p. 306. Praha.

Tesh, J. M. \& Glover, T. D. (1969) Ageing of rabbit spermatozoa in the male tract and its effect on fertility. F. Reprod. Fert. 20, 287.

Wimsatt, W. A. (1944) Further studies on the survival of spermatozoa in the female reproductive tract of the bat. Anat. Rec. 88, 193.

WimsatT, W. A. (1945) Notes on breeding behaviour pregnancy and parturition in some vespertilionid bats of the Eastern United States. F. Mammal. 26, 23.

Wimsatt, W. A. (1969) Some interrelations of reproduction and hibernation in mammals. Symp. Soc. exp. Biol. 23, 511 . 